\title{
Munich in the Nineteenth and Twentieth Centuries
}

\author{
Cinzia Leone \\ Department of Science and Technological, University of Genova, Italy
}

Copyright $\odot 2015$ by authors, all rights reserved. Authors agree that this article remains permanently open access under the terms of the Creative Commons Attribution License 4.0 International License

\section{A short cultural, social and political analysis of the city that Adolf Hitler chose as his adopted city and the cradle of National Socialism.}

\begin{abstract}
Adolf Hitler left Vienna and stayed 20 years in Munich in Bayer, before becoming the Führer of the Third Reich. The essay analyses this long period in Munich, when Hitler became the head of the NSDAP and the future Chancellor of Germany, affirming his ideology and conquering Europe. The Munich of the period under the cultural, social and political point of view is considered and the essay tries to ask the question whether Hitler should have been the same if not in the capital of Bayer. The methodology adopted is the pure research through archives and bibliographies with a strong inclination towards the cultural aspects of the impact of the new NS ideology.
\end{abstract}

Keywords National Socialism, Hitler, Germany, Third Reich, Munich, Anti-semitism, Contemporary History

\section{Introduction}

In May 1913, Adolf Hitler left Vienna for Munich, where he would remain for thirty-two years. At the turn of the century, Munich was known as the most tolerant city in the German-speaking world, in stark contrast to the Prussian Berlin. Munich was egalitarian and open, became the port of call of many and seemed to open its doors wide to everyone.

In this essay, I will endeavour to throw light on why Hitler, on leaving Vienna, chose Munich in particular, will focus briefly on the peculiar characteristics of the city and place it in its historical, cultural, social and political context, with a short excursus on the origins of the Bavarian capital.

What drove Hitler to go to Munich and not elsewhere when he left Vienna? If the city had not been what it was at that time and if it had not hosted him as it did, would Hitler still have become the architect of the Third Reich? Was Hitler a natural product of the German historical period or was he a product of the city of Munich?

Munich served as a cradle and a refuge for the leader of National Socialism: it facilitated his rise and accompanied him in the years of struggle. It was baptised "the cultural capital" of the new National Socialist era and it welcomed him on his returns home during his years in government.

It was a city that was alive from the spiritual, cultural, economic and political perspective. Bubbly and bawdy at the same time, it was the city that Hitler chose for the long period before his rise - twenty years - and he never abandoned it.

Munich was the home of beer culture and hospitality, but also of those disaffected with Weimar democracy and those who wished to affirm the right-wing and the use of force against the Jewish threat. The wish of the Führer, a new spiritual leader who could drag Germany out of the disaster of the Versailles peace, found many supporters in the Bavarian capital. The wish for redemption and reaffirmation of German power, nationalism and anti-Semitism were united in the Munich of the time.

Hitler benefitted from all of this and was hosted, assisted and politically raised by the city that was the homeland of National Socialism, which were its framework and its cradle.

\section{Munich: National and Nationalism Feelings at the Beginning of the XXth Century}

The Munich that was the capital of Bavaria at the turn of the twentieth century was going through a period of major expansion from every perspective. Economically it saw the increase of financial revenues; in social terms it experienced unparalleled immigration; politically it saw the birth of new parties and culturally saw the flourishing of increasing numbers of artists and movements.

Before the break imposed by the first world war [1], Munich had the reputation for being an open, hospitable city, the city of beer-halls, a democratic city, so much so that one commentator observed that «few other places are so democratic»[2]. The monarchs brought with them a great cultural openness and, particularly under Louis I (1825-48) and his son Maximilian II (1848-64), Munich grew culturally, hosting scholars, artists and scientists who came from all parts of the country and beyond. In the history of the city, many passed through or settled there: thus did Ibsen, Brecht, Thomas Mann, Courbet, Schelling, Wagner, D.H. Lawrence, H. Heine, Mark Twain, Andersen, Kandinsky, Rilke and 
many others. An account of the time defines Munich as the haven of the whole of German artistic and spiritual life. For this reason also, beginning from the end of the nineteenth century, Munich, traversed by the river Isar, proudly bore the title of "Athens on the Isar".

Architecturally too, the Bavarian capital witnessed a great transformation and became the triumphal city which we can still see today. The influence of the monarchs was decisive. They invested much, not only in terms of money, to encourage the development of the artistic soul of the city of their realm. Louis I, after a six-month sojourn in Italy, returned home determined to make his city become a place that no-one had ever known before, not even the inhabitants of Munich themselves. Thus he ordered the construction of imposing buildings, along with museums, theatres, great roads and squares and his work of renovation and embellishment of the city was without equal in Europe. He cultivated culture in the people and placed it within the reach of everyone through displays and permanent exhibitions. He was responsible for the creation of the Greek temple Walhalla in Ratisbon in central Bavaria, built to symbolise German unity, which was of great importance to the cult of the nation and the Germanic myth.

His work was continued in various ways by his son, Maximilian II, and by the successive sovereign, Louis II. From Maximilian on, Munich was awash with scientists, naturalists, writers and scholars from the whole of Bavaria, Germany and Europe. Some settled permanently in the city. One of these was Paul Heyse, who in 1910 was awarded the Nobel Prize for literature. Thomas Mann, as we shall see, did the same.

Louis II (1864-86), right from the start, aspired to turn Munich into the most important European metropolis for modern music and the theatre. Being a music lover himself, he personally invited Richard Wagner to perform and settle in the city. That was in 1864.

The city retained over time its acquired cultural importance and in the 1880s had more painters, sculptors and architects than Berlin and Vienna put together. The latter accurately represented the artistic vitality that many visitors found there. The artists had set up diverse cultural and professional associations and their activity was well known in the city.

Thomas Mann, in his account "Gladius Dei", recounts that in the city all of the people possessed a certain culture, from the young who went about their day whistling arias from operas, those who filled the theatres, perhaps with a cultural magazine in their pockets and who attended the university and public library.

Born in Lübeck, in 1894, at the age of eighteen Mann moved to the Bavarian capital and remained there for forty years, until he abandoned it for good due to National Socialism. He got married in Munich, had six children, wrote his first stories, the ones which made him famous, and he was there in 1929 when he was awarded the Nobel prize for literature. After the war, he returned only once in 1952. For his eightieth birthday, by this time living far from Munich, he received a congratulatory letter from his burgomaster, to which he replied:

I feel a great attachment to Munich, where I spent half of my life [...] and I have never said a bad word about it, not even when I was hearing bad things about it [...]. I assure you [...], when I hear the Munich accent it warms my heart [3].

The positive and negative aspects of Munich filled Mann's life and soul, and he loved being there. He bore an infinite love for Munich which never left him, not even after the humiliation of exile during the Nazi period, although he decided never to return there. He was a critic of the city, as one is who loves someone or something and who wants to eradicate the negative aspects. Even from afar, when he took refuge in America, he never stopped talking to his fellow citizens, to show them what he believed was the right road to take in order to emerge from the crisis which the whole of Germany found itself in. His intense pride in Munich and in Europe was clear from his radio broadcast from the USA "Deutsche Hörer!".

From America he wrote:

My European sentiment has for some time been increasing as has my German sentiment.

The news coming from the University of Munich has upset me deeply [4].

The violent contrast between his German patriotic conservatism and his firm stance on democracy were indivisible concepts in Thomas Mann. Despite all of this, within him one did not manage to cancel out the other.

But let us return briefly to the history of the Bavarian capital. At the turn of the century, in social terms Munich was evolving quickly and its metamorphosis into a major European city proved to be rather difficult. Indeed, the Bavarian capital failed in its attempt to transform itself into an industrial city, something which other major German cities had accomplished with ease. Though remaining an economically backward city, the population of the Bavarian capital increased rapidly towards the end of the nineteenth century.

At the turn of the century, almost half of the inhabitants were not native to the city. Many were immigrants, both from the East Europe and from Germany itself. Of course, significant problems arose as a result of this growth: the lack of housing, work and essential services, such as water, and the rise in prices. Hand in hand with these issues went an increase in crime, prostitution (both female and male) and the sexual exploitation of minors, while the influence of cheap labour provoked the protests of the old inhabitants of the city who were watching their jobs disappear.

Accompanying the economic transformations were other great social changes. Towards the end of the nineteenth century, the importance of the aristocracy began to diminish noticeably, in direct proportion to the rise of new categories of professionals who represented Bildung und Besitz [5], which emerged during the revolution at the half-way point of 
the nineteenth century and which, after 1871, went from strength to strength. The traditional class divisions with the aristocracy, the upper-class, the Mittelstand [6] and the other classes were challenged by a strong mobility, which intensified wherever there was an intense flow of migrants.

In Munich, the conversion of the city into a major urban centre therefore brought with it social changes, which reverberated in the political transformations. For the whole of the nineteenth century, the economic and academic elite had played a dominant role. This strongly consolidated elite had an influence that was not proportional to its number, but directly linked with the power that it could wield thanks to the limited right to vote, which favoured it excessively, thus antidemocratically, and therefore allowed the preservation of power. But things began to change.

Though very active culturally and with quite a developed international tourism, Munich was not a cosmopolitan city as Paris or Vienna might have been, but strenuously maintained its Bavarian character and the strong sense of belonging to the region of which it was the capital. The reunification with the Reich, which took place in 1871, represented a point of departure, of crisis, but also a new deepening and reinforcement of its own identity. Bismarck and Prussia tried everywhere to stamp Prussian identity on the Germanic territory, but the Kulturkampf which began after the unification of the Reich did not have any great appeal in Bavaria. As a reaction to the political change which was taking place within the German state and to this elite which had exclusively dominated until that moment, in Munich the desire for democratisation and the social turmoil translated into the birth of different movements and political parties in a relatively short period of time.

Thus, in 1868, the Patriotenpartei was established in Munich. Founded by Catholic militants, it had already gained a majority in the elections for the Bavarian Landtag. Emboldened by their political power and representation in the Landtag, they fought both the cultural and political liberalism of the Bavarian monarchs and the Kulturkampf.

In 1896, the Social-democratic Party was founded in the city: with a strong reformist and pragmatic mindset, this new political grouping immediately managed to gain $14 \%$ of the vote [7].

Bavaria, a traditional land, viscerally attached to the age-old values, needed a change, something strong, a party that was social-democratic and made up of patriots who could defend their own identity, far removed from the liberalism which represented the danger of the corruption of the tradition and similarly far removed from the unloved Prussia.

There were many dangers that threatened to undermine the strength of Bavarian traditions: progress, industrialisation, and liberalism, but also unemployment, social corruption, the waves of newly arrived migrants, the Kulturkampf and the rivalry with Berlin. As has often happened in history, in Munich the main danger for many people came from the Jews. In this way, different parties and cultural associations began vigorously to spread anti-Semitism, identifying the
Jewish enemy as the source of so many of society's ills. The growth in Jews present in the city, although relative, was accompanied therefore by the increase in hatred for them.

The number of Jews at the time, however, remained quite small. If we consider that the population of Munich increased to almost 600,000 people in 1910 and that the Jewish population by the start of the new century barely amounted to 10,000 , making up $1.5 \%$ of the city's total, the anti-Semitic drive appears even more unjustified. Not that it would have been otherwise.

In the preceding period 1875-1899, the number of Jews increased in Munich at a rate of about 220 people per year in 24 years, for a total of 5,288. The Bavarian capital in 30 years, on the other hand, increased in population by $259 \%$, rising from 230,000 people in 1880 to 596,000 in 1910 [8].

In Munich, there was the largest Jewish community in the south of Germany, but this community could not be compared with those of cities such as Vienna, Prague or Berlin. The Jews arrived from Galicia, Poland and Russia, as well as from the rest of Germany, in line with the general flow of migration. Nevertheless, the University of Munich was said to be a "secularised secondary school of the Talmud"; anti-Semitism reverberated in the magazines; it could be heard in the popular songs. What was palpable was a biological determinism that was spreading among the people.

Precisely here and precisely in this context, another new party was founded in 1891. It was called the Deutsch-SozialerVerein (DSV - German Social Association), a strongly anti-Semitic party, which supported the expulsion of all Jews from government positions, the decrease in the percentage of Jews in professional categories and the limitation of the possibility of migration to Munich.

Also based in Munich was the propaganda centre of the AlldeutscheVerband (t.i. all German Union). This movement propagated an extreme nationalism, a strong aversion to anything that was not German - foreigners and Jews included - and expressed, not without reference to anti-Semitism of a Christian bent, the "hope that Germany would produce a new Luther, a man that could carry forward a struggle". They were awaiting a messiah, someone who would turn back the tide of German misfortune, one who would revive the great Germanic dream that had never died.

The fact that a new leader should rise - a Führer - who could fulfil the expectations of a people of followers, was a very widespread conviction among right-wing groups, and not just among them. The leader was conceived not as someone who would use dominion over others by virtue of his political position or power, but who could become the one who possessed this gift, this instinct, a characteristic that was innate, natural, recognisable from outside and identified by those around him. Someone therefore endowed with features that made him unique, capable of taking on great responsibility, of leading the German people in his own right, without hiding behind organisations or structures. In this there found expression the Weberian idea of the leader and the Weberian being, the assertion of power even in the face 
of an opposition thanks to his charismatic legitimacy, which rested its firm foundations on the sacred and sacral character, on the heroic strength and charisma of the person. This represented that Führerprinzip, who found embodiment in the figure of Hitler and that he himself used when it came to ridding himself of any formal constraint, from any construct of the state apparatus, to focus all powers on himself and in his hands.

These principles were always present in the German mind and took inspiration therefore from a profound need of the soul. No community could be without a strong leader, no nation without a Führer: there is only perdition and vain hope in the community without a leader who gives sense and direction to society, followed by a nation of adepts with a strong sense of obedience, loyalty, duty and of the task entrusted to them.

Thus, in disseminating their ideas during the decades, the opponents of democracy made possible the advent of a Führer. In public opinion also and in the press, day by day the idea that democracy was not suited to Germany was increasingly establishing itself, that it was too weak a creation, while there was the strong need - real and emotional - to found a new state whose unity and strength had to be represented in the figure of a Führer in whom the people would trust. The role of leader would not then be limited to the German territory, but the Führer would promptly take the reins of Europe, the Europe that was dispersed and degenerate because it was in the hands of the French and English, the Europe that had dismantled the German army, occupied part of its territory and dared to humiliate Germany, leaving the political leadership of the country in the hands of a few democrats, with a weak democracy like the one on which the Weimar Republic was founded. Germany, in this way, recovered its global mission as leader and the anti-liberal attitude to the state was embodied in the idea of the Reich. All of the above had its natural fulfilment after 1933 .

The force of attraction exercised by German National Socialism, which we are going to clarify here and below, above all at the beginning - was a primarily spiritual thrust aimed at overcoming the isolation of man pushed by many forces towards individualism and at creating a social and nationalist being, national socialist that is. The German man was going through a difficult period; he was shocked by the loss in the war, the submission of Versailles and by the economic and political crisis. The way out of a situation of hardship was not a physical retreat from those factors which had caused the unrest, but was a refuge in the values lost which could have offered safety. In this way, capitalism and industrialisation and the negative things they bring with them were not entirely rejected, but refuge was found firstly in the spiritual and secondly in the political sphere. The latter would represent the realisation of what had already been conceived, created and experienced spiritually, according to that pietistic tradition, reported in Mosse's essay, for which the homeland is within everyone:

Germany? $[\ldots]$ no-one knows where it begins and where it ends. It has no borders, Sir, in this world [...] it exists in our heart $[\ldots]$ or it will never be found anywhere [9].

When such ideas and yearnings took hold in German society, it was going through a strange period from every point of view. We have already spoken of the weak democracy, of the economic reforms and of the advent of industrialisation; we have also pointed out the fact that the middle-class was losing its importance and no longer represented a sure reference point. The scuttling of the middle-class forms of life brought with it the wrecking of the foundations of society and created that feeling of uncertainty which united with the insecurity and fears which were already present and which were determined by other factors.

The fact that in Munich, more than in other cities, in the period in question between the Nineteenth and the Twentieth century, armed groups of all kinds were formed for the purpose of defence, but also for the re-establishment of order, constitutes a strong testimony to the desire for security linked to the force of arms that could not be appeased through a treaty such as that of Versailles and for which Weimar had no answer.

In this time in history, some found in the philosophy of the Führer the way to deliver the German race from the danger of contamination with other races and the assertion of German superiority («We are not like the others, we are Germans» was to be heard from the nationalists), seeing Germany as the mother of all peoples who, precisely as a mother should, in the middle of suffering and defeat throughout history, has always given new life and been a blessing for other peoples. This was a mythical idea of the German mission that had deep roots and a broad space in the collective imagination. The reborn Germany, which was strengthened and ready to rule, would have "cured" the "sick" Europe, sick because its main component, Germany, was weak.

Poets and writers with their verses accompanied the wish of the German people and sang about its future. This von Wallpach did when he spoke in 1900 of the "need for living space" for the Germans; thus, in 1925, Reifenberg championed the destruction of France through the use of large airplanes. One could go on. This was the period that Germany was living through at the turn of the century: that of a dream that had by that time taken root in the consciousness of many and one that Hitler himself became aware of by reading these texts and by living in Munich.

An important role in Germanic nationalism was, moreover, played by festivals and by the Festspiel, theatre productions in the form of popular festivals, which had a long tradition throughout Germany. In Bavaria, in particular, many festivals for the people and the masses took place in the beer-halls. These, with their wide spaces and open air gardens, served as a gathering place for everyone: at low prices one could drink, eat, celebrate together and live that «beer philosophy» which distinguished Bavarians from the rest of Germans. Some Munich beer-halls, still in business today, managed to hold thousands of people in one closed space and Hitler himself chose a beer-hall right in the city 
centre as the official gathering place for his movement: the Bavarian winter has always been very severe and one could meet there warmed by flowing rivers of beer. Furthermore, for a political meeting in a private place, there was no need for the permits that were required in a public place, and above all, the people commonly met in a jovial setting over a beer, with traditional music, and also to listen to a political speech. Hitler's putsch, the unsuccessful one of 1923, took place indeed during a meeting of representatives of the Bavarian government in a large beer-hall in the capital.

A small focus, therefore, on the importance of popular and national festivals. George L. Mosse has made an in-depth analysis of the impact that they had on the German people and on the masses in various essays. In The Nationalisation of the Masses, starting from the German experience, the historian analyses the importance that tradition had in the psychology of the masses adopted by the national socialists, who, as in many other fields, did nothing other than use and optimise techniques, ideas and practices already present.

The festivals opened with parades with floats with Schillerian themes, with people who paraded carrying flags, and they were intended to make men more virtuous, thanks to their participation in the collective ritual, an expression of love for the homeland, which elevated man above his daily routine and projected him into the realm of the spiritual, where «the inevitable result of beauty is the freeing of passion» $[10]$, that passion that was freed during the celebrations and which expressed the beauty of the nation finally united under a single ideal.

This type of celebration was then copied by the national socialists - around 70 years later - to commemorate those who died in the 1923 putsch and others of its kind followed. In these events, the magical and mythical element achieved increasing prominence: appealing to the irrational, it arrived to unify and strengthen a people politically divided and not spiritually cohesive enough. Political life, with the passing of time, became, above all in the national socialist period, a representation of a cult and a ritual, a veritable theatrical performance, with so much set design and direction.

The spaces were also conceived and designed in such a way as to be the setting for immense events, where the actors were the people and the scenic design was the grand monuments which encircled and surrounded them. This idea of monuments and open places to have the people meet in preceded the advent of National Socialism. During the eighteenth century, the German historian and archeologist Johann Joachim Winckelmann and his idea of objective beauty had already reawakened the aesthetic sense of the German people, by making them turn towards that past of nobility and beauty and leaving them yearning for past beauties, and by attempting to reproduce it in the present. The Greek man became the ideal who was then compared with the stereotype of the Jew, who represented the opposite of the beautiful. The symbols had to help to bring out from the people the beauty that they sheltered in their hearts. These ideas constituted the foundation of the German aesthetic for the whole of the nineteenth century, when both classicism and romanticism were founded on the idea of the nation, on the ideal German type, on the idea of the beautiful and that which it depicted. This happened only in Germany, a territory which saw the rise of monuments of all kinds which were aimed at the celebration of the German people. In Bavaria, several were erected with the intention of reawakening and keeping alive the ideal of German unity, the German spirit that was unified in the symbol that it adopted from ancient Greece. Bavaria became the land of Germanness, where nationalist theories would be kindled. Nazi architecture would make its own all the ideas that preceded it, beginning from the rebirth of classicism and moving from romanticism. One example of this is Walhalla, which was the reproduction of a Greek temple, built from 1830-42 to symbolise the ideal of German unity. Over time, the Greek model became völkisch[11], a model which the German people appropriated. Various architects who dedicated themselves to applying the new ideal of beauty in their constructions contributed to this: Gilly, von Klenze, Semper, Kreis and many others left traces of the realisation of these ideals in architecture and also in their writings, a style that had to be recognisable to all of the people and which should have immediately been a summons to unity, a sort of reference and sudden commemoration of the self-awareness of the German people, which found externally that which lived for years within its hidden inner life.

The monuments with their vast contiguous areas were meant to be the external expression of the sacred internal space, which, precisely according to the German pietism tradition, was enclosed in a man's soul. Thus, in Bavaria, one may still today see these great and grandiose monuments, designed to host thousands of people united by the national spirit. The Nuremberg complex - a colossal work conceived by the national socialists for their immense rallies - was intended to be its highest expression, but it was never completed. The people in these immense rallies outwardly found interior fulfilment in the theatrical and stage performance of a common national feeling, of the undivided nation, finally united by a single destiny.

A brief aside on Bavaria, which was historically the protagonist of this national rebirth, thanks also to so many monuments and symbols bequeathed by Louis I. If, in the period preceding 1871, most German monarchs in no way wanted to consent to the assertion of national ambitions, but conversely saw it as a danger to their power, the only case in the panorama of the various German states before unification was represented by the sovereigns of Bavaria, who instead focused expressly on national sentiment and sustained it also through the construction of monuments and the cultivation of the cultural substratum of the German nation. There one found therefore a developed national sentiment even before it became widespread in the rest of the German territory and even before it became a nationalist sentiment. But things changed somewhat after the unification of the Reich in 1871, when the rivalry with the Prussian capital, Berlin, accentuated the Bavarian national sentiment in full contrast 
to the Prussian one.

From the above and also from other ideas, which for reasons of brevity I have not been able to analyse here, one easily arrived at the idea of the Reich, which became established with the coming of Hitler.

The decisive meaning of the idea of the Reich lies in the fact that it gives a positive value to the present of Germans. [...] Through the faith in the Reich the memories of the past and the unresolved problems are not reawakened, but the hopes for the future are also strengthened [12].

All of this was accompanied by new ideas on the people, nation, society and liberty. This was supposed to work, also from the ideological point of view, for the new foundation of the state-overcoming the historical aversion to Prussia in itself, with a safe leader, in which the people were subjugated and the concepts of people and nation were founded to form a unicum that would help the success of the new state, by identifying with it. In all of this the person would almost lose their own identity to merge with that of the state and their peers, united internally by the same profound yearning for unity and therefore willing to sacrifice their own sense of self in favour of the nation.

In Munich at the turn of the twentieth century, the climate was similar to that of the rest of Germany. Here, Hitler almost immediately met someone who made him what he became, someone who was waiting for a gifted person, predestined to become the Führer of a nation by now on its knees, which desired to recover and rise again: Dietrich Eckart. There were many right-wing scholars who with their writings rode the waves of social protest which arose from all sides and which sought an end to Germany's humiliation. Eckart was one of these. Bavarian, he was born in Nuremberg in 1868, the son of a wealthy judge. A morphine addict, alcoholic and drug addict, who also ended up in a psychiatric clinic, he became a writer, but always led an entirely profligate life, so that he had various sojourns in homeless refuges. He considered himself a genius and had great success in Germany; in his writings he expressed a pathological hatred for the Jews. Having lived for some time in Berlin, in 1915 he moved to Munich, where he introduced Hitler to the high society and the circles that would support him in his political rise.

The premature death of his mentor, which occurred in 1923, never erased Hitler's memory and recognition of him. He dedicated Mein Kampf to him and he expressed the desire to let him build a monument in their Munich, that city that had hosted both of them and which by that time represented a focal point for those disaffected with Weimar:

Munich is at this point and has been for a long time a centre for all of those who fight in an antidemocratic manner against the Weimar Republic: in the city one meets the remains of the counter-revolutionary Freikorps, the eternal stalwarts of the old army, unemployed officers and ex professional soldiers, influential people of the Thule and students of the radical right, survivors of the Kapp putsch,
anti-Bolshevik emigrants from the Soviet Union, philosophers and occultists, adventurers, careerists, servants and society's marginal figures[13].

Munich in the period after the First World War represented a cross-section of German society, with some aggravating circumstances. There are many studies that, in Germany, have analysed Munich society specifically to understand the origins and roots of National Socialism. In the post-war chaos, nostalgia for a new community founded on order and discipline - those values of the era of Wilhelm that had diminished - began to grow [14]. This was all in opposition to the era and to bourgeois liberty which was becoming established throughout Europe. The world appeared confused and there no longer was the certainty of German power, of its supremacy in the European world.

Joachim Fest, in his masterful biography of Hitler, maintained that his ascent was certainly facilitated by the historical conditions in which it took place, but that one may absolutely not overlook the particular historical conditions that affected the place of his rise, i.e. Munich. All of this was accompanied naturally by the personal characteristics of Hitler himself, which led him to become the undisputed head of the movement and of the German nation. Hitler had within himself those gifts that Eckart had noticed and which are thus summarised by Fest:

No less important was the importance of the strength of will aimed at the achievement of the goal and the importance of the reflection that he offered. And, that is, he possessed a sensibility out of the ordinary, effective and feminine, which rendered him able to articulate and take advantage of the spirit of the time [15].

Fest then describes Hitler as a person capable of conquering with his ars locutoria, which was cold and slow and rational and aimed at the building of a consensus.

\section{Hitler and Munich: The Reasons for a Success}

Munich became, within the space of a few years, a focal point for the unhappy and the dissatisfied and the creative centre for new movements that were extremist or, in any case, right-wing. In Joseph Roth's novel Das Spinnennetz, the main character, an ex-soldier and veteran of the Great War, lives in Berlin. The secret extreme right-wing association that he belongs to receives orders from Munich and the leaders sometimes go to Munich, to better coordinate with the headquarters.

One of these movements was the party that would make history thanks to one of its members, Adolf Hitler. The Deutsche Arbeiterpartei (DAP, German workers party) was formed on 5 January 1919 in the shops of the Munich railway by the toolmaker, Anton Drexler, along with Karl Harrer, Gottfried Feder and Dietrich Eckart. In the same year in Munich, there numbered about fifty political groupings, 
whose names echoed their intent: NeuesVaterland, Ostara-Bund, BundsozialerFrauen, Siegfriedring, FreieVereinigungsozialerSchüler etc. The DAP also belonged to the ranks of these associations, which proliferated in a period of social uncertainty and new political awareness.

In the DAP the appeal to the working classes, on which the party focussed its attentions in Bavaria, was clear, but it was not exclusive to them. Drexler had also published an autobiographical work with the subheading "Diary of a socialist worker" and believed steadfastly in the need for a political reawakening of the working class. In reality, the future national socialists (the DAP would change their name to NSDAP, NationalsozialisticheDeutscheArbeiterPartei) were never satisfied with progress made between the workers and the party and the latter would never be a mere party of the workers.

The city of Munich therefore functioned as a launching pad for a new political style, where it nurtured and accompanied Hitler in his rise, constituting an ideal landscape for the Nazi parades, like a dress rehearsal for what would happen after he had taken power.

The social microcosm that the Bavarian capital captured in the period from the end of the nineteenth century until Hitler's coming to power in 1933 may represent an excellent field of study for anyone investigating the period that precedes the Ermächtigung in search of the causes or contributory factors that led to the coming of Hitler.

Some limit their research to the communist peril which those in Munich saw up close during the Council Republic and the terror that it brought with it, during the aborted tentative which lasted only few months, by side of communists and socialists to take over the power in Bavaria and which ended with a bloodshed. The rebuttal of these theories, which are a little simplistic and limiting, has come relatively recently. For example,

Joachim Fest disputes the causal link between the extermination of the Jews and the threat of extermination of the Germans under pressure from communism [16].

Of course, if the Bolshevik peril could not absolutely represent the single and principal motivation for the success of Hitler's movement, it was certainly one of the factors that fostered it, as asserted by Hitler himself in various speeches and summed up in the following concepts:

Hitler, due to his education, due to the radical anti-Semitism already present in Mein Kampf, due to his idea of bolshevism as a Jewish creation, renders the mediation of his conscience the creator of the causal link as a historical fact [17].

This is what Scoppola maintains, connecting in some way Hitler's forma mentis with the creation of the cause-effect relationship between the causes represented by the communist peril and by the hatred for Jews and the effect that it produced, i.e. the advent of the national socialist regime, as a natural result given the historical circumstances.

In this case, in Munich there was a dense atmosphere of intolerance of the communists (above all after the defeat of the Council Republic) and violent clashes were recorded daily between adherents of different factions. Often at the university, where right-wing youth groups were active, the left-wing lecturers - or those considered thus - were attacked and their lessons disturbed or obstructed. More serious skirmishes or clashes were not infrequent between opposing groups in the streets of the city. There was a high level of tension. It therefore was no coincidence that the hard core of Hitler's party was founded in Munich and developed there, becoming National Socialist even before the party itself had been formed. There, it was easy in those years to meet someone who would willingly and without a second thought have embraced and ridden the waves of extremist protest, either in left or in right-wing. People like Hans Frank, Alfred Rosenberg, Rudolf He $\beta$, Hermann Göring, people of importance in the future Third Reich, were all students in Munich, who met each other with the remains of the counter-revolutionary Freikorps, eternally loyal to the old army abolished by Versailles, with unemployed and demotivated officers, ex-professional soldiers, influential people from the Thulegesellschaft and young students of the radical right, survivors of the Kapp putsch, anti-Bolshevik emigrants from the Soviet Union, philosophers and occultists, adventurers, careerists, servants and society's marginal figures.

All of these people were in search of their own personal affirmation; some were pure Nazis, while others were true champions of a new political style and strenuously awaiting a radical change. The factor that often attracted them to the national socialist party was not political, but was above all a desire for camaraderie and the search for a hierarchical link. As Joachim Fest points out, the part played by Göring and his beautiful Swedish wife contributed then to opening the eyes of Bavarians to the fact that people existed outside Bavaria, making them reflect on the possibility that local political movements could spread elsewhere.

Until then politics, and also the Bavarian kind, had been for the elite, the bourgeoisie, detached from the masses, where the people did not participate in political decisions. National Socialism offered a valid alternative and the chance to believe in a general will which could be asserted to protect the nation and a higher ideal, distancing itself from liberalism and communism, which had satisfied no-one. In rural Bavaria, many in the countryside were far removed from the lifestyle and mentality of city life: they lived distant from politics, were conservative and fearful of any upheaval that might be presented to them. They had particularly suffered the aftermath of the war and the consequent economic crises and were not particularly active from the political point of view. Many of them were taken with National Socialism, also because the new political style called for the direct approach to whoever had not been politicised up to that moment. It is a well-known technique to try to recruit to their party those who had previously shown 
no interest in politics. The National Socialists, above all at the start, invested huge effort in conquering rural Bavaria, certain of a success that arrived only partly however. They spoke directly to the people in plain language, with direct examples taken from daily life. They were ordinary people, who may have grown up in the areas in which they spread their political propaganda, spoke in dialect and for this reason proved more credible.

The NSDAP also responded to the desire for security and order which was innate in the Freikorps and in the armed clandestine groups (Einwohnerwehren), an entirely German phenomenon which is worth noting for the implications it had on German history. These military associations represented the «development of a heroic-military counter-culture with regard to bourgeois society» [18] as a reaction to that bourgeois society that had brought only discontent and that continued to disintegrate along with the republic. The various associative forms which grew dramatically in a short period of time - in a territory such as Germany which was quite circumscribed - were marked by the pre-liberal ethos. It absolutely did not include the bourgeois values that also in some way, albeit more weakly than elsewhere, had been affirmed beginning from the French revolution. Reichshammerbund, Dürerbund, Germanenorden, Thulegesellschaft, Juniclub, Herrenclub, Mittwochgesellschaft, FreikorpsEpp, Einwohnerwehr, Nationaler Club von 1919 and many other groups supported the assertion of force where society was weak, used anti-Semitism as a positive value which helped the return to cultural values of a divided and weakened nation and bore arms when the Treaty of Versailles had banned them.

The case of the Einwhonerwehre (citizens' armies) of the cities that developed in Germany, as already touched upon, constitutes a historical case without precedent. The years before the First World War saw Bavaria, as we have said, as a focal point for right-wing and extreme right-wing groups and factions. The Kahr government was the first opponent of the politics of reduction of the German military capability and in his Bavaria he did not resist the formation of armies, even clandestine ones, but above all armed ones.

Gustav Ritter von Kahr (1862-1934) was an important figure in Bavaria. A legal expert, son of the presiding judge of the court of Bavaria, he became the first advocate of the conservation of the tradition of his country and founded the BayerischenLandesvereinfürHeimatpflege, with the intention of preserving Bavaria from the corruption of the surrounding world. In 1920, he became the prime minister with his BVP (Bayerische Volkspartei, Bavarian People's Party) party and continued successfully with his intention to make Bavaria an Ordnungszelle, an ordered and safe isle, which was preserved from the communist peril. The order of Bavaria, according to Kahr's belief, was not then threatened solely by communists but also by the "Judaized" Weimar Republic.

During his government, the citizen armies and other voluntary armed groups were in no way impeded and reached three thousand members, having among their ranks not just ex-soldiers, but also adventurers of every kind, ex-convicts or survivors of the Kapp putsch, ex-members of the Freikorps of the eastern territories, assassins, supporters of the armies of Ludendorff, opponents of the republic at every level. With the addition of the historical intolerance of the forced Prussianisation and "Judaized" politics, with such appeals they very easily achieved the aim of collecting a vast number of thugs willing to do anything, but above all to use force in order to protect the Ordnungszelle of Bavaria in danger.

The reaction to the bourgeois world brought with it the rediscovery of anti-Semitism which, as has often happened in history[18], served as a lever with which to raise up those masses who up until then had been excluded from social and political life. The uncertainty of the status of the upper classes, together with a strong wave of politicisation and movement of the lower classes, had as a result undermined the society which was wounded up to that time. The leading role that the middle class had performed was challenged: the protection of corporate or vested interests was associated with the bourgeois world and the Jewish instinct, to be denounced and subverted.

It was easy then to return to the primordial instincts, to the descendents, to the race, to baser values that spoke directly to the blood of the people. It was no longer an elevated political philosophy, destroyed first by the failure of the war and then by Weimar. Compared to the politics of Weimar, the alternative of the NSDAP as a protest and counter-action, or better, a polar opposite, could seem acceptable to many.

The masses of people who were insecure and without great alternatives for their own future therefore easily flowed into Hitler's party, which in the meantime had perfected its mechanisms for the mobilisation of the masses.

The age factor of the NSDAP was not to be underestimated. The continuous influx of young people had led to a drop in the average age of the party's supporters from one year to the next. This was until 1925, when it began to rise again, since one of the dictates of the reorganisation of the party by Hitler was that the supporters had to be at least 18 years old. But let us take into account the fact that in 1923 , the year of the putsch, $47 \%$ of the members were younger than 24 years old [20]. If on the one hand the first justification for such an enormous presence of young people in the party is demographic, this cannot be sufficient. We have already said it: Munich and the whole of Germany were flooded with hundreds of thousands of soldiers who were young, who had left the army due to its reduction according to the Treaty of Versailles. Unemployment was constant and there was no great future for young people. Far removed from politics and needy of attention, they were naturally attracted to this new movement. In those years, the party was radical and therefore able to attract the disaffected young, who were thirsty for a future and some action. Its tendency to be a young party, because it was made up of young people, was maintained over time, at least according to the data available until 1934. 


\section{Discussion and Conclusions}

Many people over time have variously interpreted the success of the NSDAP, tracing similar motivations but also opposing ones. In the years immediately after the Second World War, more emphasis was placed on political disillusionment, considering the economic depression which brought social disaffection with it as a lesser factor. Others have read into the vast national socialist following the idea that young Germans were fated to adopt a totalitarian ideology, dictated mostly by psychological factors. Some still maintain that the NSDAP found great success because it found a fertile territory in the anti-Marxist and anti-Semitic Germans on the one hand, and in the militarist and activist Germans on the other. Of course the trauma that such a long period of war brought with it and defeats such as those which the German people had to deal with could have left no people unaffected. The fact that people of every social class supported Hitler's party tends to make us naturally agree with those who do not want to put the national socialist success down to socio-economic frustration per se. NSDAP, for many, has been seen as a party reacting to the existing party system, but also as a small-minded and vulgar reaction of a people who had become the prey of anti-intellectualism and who willingly took refuge in the so much emphasised Herzensbildung. This represented a liberation from the constraints of the intellect towards the freedom of the primordial instinct, the Germanic one. Formal knowledge was gradually substituted by emotional values and by magical elements. Thus, for example Kater tells us of a Bavarian teacher who became a fervent Nazi:

The Halbbildung of many national socialist leaders with its deep roots in self-education, in axiomatic systems and the characteristic absence of logic were evident in the case of a public school teacher in Franconia, Hans Schemm, who then became a Gauleiter. This admirable son of a shoemaker, with a clear sense of imagination and spiritual agility, was a devoted chess player and admirer of Goethe, Richard Wagner and Nietzsche. He became a part-time chemist and also a biologist to a small degree. Mixing his knowledge with a little prejudice and the convictions widespread in the lower classes of society, not only did he become a fervent anti-Semite, but he felt how right it was [21].

The supporters of the National Socialist Party did not need to be elevated exponents of the cultural or intellectual world, because the party offered itself as an alternative to the whole world that had preceded it; it offered a new beginning, a new culture, the overcoming of the past and of the "degenerate" culture.

Finally, among the highly successful national socialist motivations, I would like to advance the spatial-temporal position of the party, which is of great importance: Munich and Bavaria, a land that was conservative, religious, monarchist and traditional, following and honoring what was thought by many people who lived or visited this land and according to what was said in the town during those years:

Ancient faith and ancient beer is still the best that we have in Bavaria [22].

No-one would ever have hypothesised that the Bavarian capital could represent such a perfect launch pad, but Joachim Fest too - and other scholars along with him attributes to the place a fundamental importance.

It is abundantly evident that Hitler's success may not be explained by starting from an exclusively interpretative point of view, or by basing an argument on partial presuppositions or by binding oneself to a historical period in which the analyses are carried out. Thus, the role of Munich in Hitler's rise has also not been properly considered, because immediately after the destruction of 1945, the whole of the West, which was about to write its history, was taken up with recovery, by the fall yes, but also with constructing a valid defence against the communist peril in nearby Eastern Europe. For a long time it has been very easy to isolate the figure of Hitler by extrapolating it from the spatial-temporal context and restricting it to a mere personal political fact.

Here, however briefly, I have tried to demonstrate how the set of historical, spatial, political and personal factors constituted, with its base in Munich, that fundamental substratum without which - along with external factors such as German politics of the period, the international situation and Versailles - Hitler, in all probability, would not have been what he tragically was.

\section{REFERENCES}

[1] The First World War developed in Europe within 1914 and 1918 and upset Europe: after the end of this war the European framework was overturned. The order of some monarchies or empire dominating till 1914 was messed up and new national countries were born. Germany lost the war and was submitted by the winners to withstand with a Peace Treaty signed in Versailles in 1918. Thanks to this settlement, Germany lost part of the territories, underwent to the dominion of the winners and economically brought to the knees. On the remains of old Reich of Germany a new republic was born: the Weimar Republik. This was weak since its birth and the diktat of Versailles together with the arising political, social and economical crisis were surely the premises for the Second World War (1939-1945), which saw Germany again among the protagonists.

[2] D.C. Large, Hitlers München, Munich 1998, p. 10. This is taken from a statement contained in an article by an America traveller who in 1909 wrote a piece entitled «Munich - A good-natured city»).

[3] Drawn from the collection of writings of T. Mann by the Süddeutsche Zeitung in the essay entitled München leuchtete, Ulm 2008, p. 10.

[4] T. Mann, München leuchtete, cit., p.10. The broadcast "Deutsche Hörer!" was led by Thomas Mann for the BBC during the period October 1940-May 1945 once a month. 
Here Thomas Mann spoke about the political situation in his homeland with clear critics to the NS. Mann was in the USA since 1938, when he decided to move from Europe because of the political dangerous turns in Germany.

[5] The expression Bildung und Besitz represents the set of factors of upbringing, education and the possession of wealth.

[6] A term which dates from the late eighteenth century, used to refer to the best-off classes of society and which then by extension, beginning from 1848-49, was applied to all of those who were socially above the workers, encompassing the whole of the middle class: independent traders, merchants, artisans, academic professionals, entrepreneurs. Finally, the increasing number of white-collar workers and higher-level government employees were included in this definition. At the start of the XX century, some scholars identified two sub-categories within the Mittelstand: NeuMittelstand, composed of white-collar workers and bureaucrats; Alt Mittelstand, composed of independent workers. It remains very difficult, however, to delineate precisely the division of German society into classes, as reported - likewise with regard to the text of this note - by M.H. Kater, The Nazi Party - A social profile of members and leaders - 1915-1945, Oxford, 1983, p. 1 et seq. Some ideas which follow are also taken from the same text.

[7] Different ideas here exposed are from: Kurt Sontheimer, Antidemokratisches Denken in der Weimarer Republik - Die politischen Ideen des deutschen Nationalismus zwischen 1918 und 1933; München, 1978.

[8] Here and the above paragraph: source D. C. Large, op. cit., p. 20. Elaborated by me.

[9] Cit. in H.F. Pfanner, Hanns Johst, The Hague, 1970, p. 151, cit. in G. L. Mosse, The Nationalisation of the Masses, Bologna 1975, p. 242.

[10] G. L. Mosse, The Nationalisation of the Masses, Bologna 1975, p. 109. Various ideas explored here are taken from this essay.

[11] This adjective actually means ethnic, also "of the people", folk, but is used also in a nationalist sense and connotative of the race.

[12] K. Sontheimer, cit., p. 242.

[13] H. Wilhelm, Dichter, Denker, Fememörder Rechtradikalismus und Antisemitismus in München von der Jahrhundertwende bis 1921, Berlin 1989, p. 97. For Freikorps and Thule see below.

[14] The "Wilhelm era" became famous in Germany as an expression linked to the person of Emperor Wilhelm II, King of Prussia (more or less the current Germany) in the period 1888-1918. With his person the monarchy ended, because after the First World War (1918) Germany was settled no more as a monarchy, but as a republic (see note No. 1). During his long reign, Wilhelm gave Prussia order and safety as never in the past, affirming his autocratic idea of a German realm, based on iron and starkness. He proceeded to uniform the inhomogenous German territory under the Prussian order and affirmed the power of the arms, but gave the population social welfare and social order.

[15] J. Fest, Hitler - Eine Biographie, Berlin 2008, p. 200. About the terror accompanying the Republic of Councils: this was a very short attempt to establish a socialist state in Bavaria. It developed under different forms from November 1918 and ended with a bloodshed on May 1919. The founder was Kurt Eisner, a famous German politician, who declared the new socialist state on the anniversary of the Russian revolution. The few-months-government evolved in executions and lack of freedom. The end was thanks to the so called white troops (right-wing armies) who marched on the capital, Munich, and hundreds found death, due to the final fighting in the town streets. After this, the Bavarian population and the Germans in general remembered for long times the events in Munich and the fear for communism was long lasting.

[16] P. Scoppola, Lezioni sul Novecento, Bari 2010, p. 14.

[17] Ibidem, p. 15.

[18] H. Mommsen, Der Nationalsozialismus und die deutsche Gesellschaft - Ausgewählte Aufsätze, Hamburg 1991,p. 15.

[19] The use of anti-Semitism as a political instrument has far origins in all European countries till to Russia. In the history of the so-called Old Continent, that is Europe, the persecution against Jews has been often used by side of the power, when the population was not happy with the political situation, as a tool to distract people against who was always considered as a foreigner or as an enemy, the Jewish population, who served as scapegoat. This was the case of the Russian Empire, where Jewish persecutions were periodically adopted as a political means, this was the case of the Spanish monarchy during the Middle Age and the case of the Habsburg Monarchy till Francis Joseph (1830-1916).

[20] M.H. Kater, op. cit., p. 239 and following.

[21] M.H. Kater, op. cit., p. 185. Halbbildung stands for "half culture", that characteristic typical of many Nazi exponents, for which culture and intellectual elevation were inversely proportional to the ideology which permeated it, which lay in the heart, in the inner life (Herzensbildung).

[22] J. Pezzl, Alter Glaube und altes Bier ist noch das Beßte was wir haben, in Reise durch den baierischen Kreis, Salzburg 1784, piece reported in I. Karl (Hrsg), München - Eine Lese-Verführung, Frankfurt am Main 2010, p. 73. Pezzl was a writer and Bavarian librarian who lived in the eighteenth century. There are many authors who, although passing through described the Bavarians as strongly attached to their tradition and the custom of convivial beer-drinking. Thus also did Th. Mann, but also Guillaume Apollinaire.

\section{Translations}

All translations are from original texts translated by the author of the present paper.

[1] AAVV (Mommsen et al.), Totalitarismo, lager e modernità Identità e storia dell'universo concentrazionario; Milano, 2002

[2] Henry Ashby Turner, Jr., Die Großunternehmer und der Aufstieg Hitlers; Berlin, 1985

[3] Zygmunt Bauman, Vite che non possiamo permetterci; Bari, 2010

[4] Werner Bergmann, Geschichte des Antisemitismus; München 2004

[5] Martin Broszat, Der "Staat Hitlers" und die Historisierung 
des Nationalsozialismus; Göttingen, 2007

[6] Martin Broszat, Da Weimar a Hitler; Bari, 1986

[7] David Clay Large, Hitlers München; München, 1998

[8] Brian Deming and Ted Iliff, Hitler and Munich; München, 1998

[9] Ernst Deuerlein (Hrsg), Der Aufstieg der NSDAP in Augenzeugenberichten; München, 1974

[10] Joachim Fest, Hitler - Eine Biographie; Ulm, 2008

[11] Lion Feuchtwanger, Erfolg; Berlin, 2008

[12] Hermann Glaser, Wie Hitler den deutschen Geist zerstörte; Hamburg, 2005

[13] Sebastian Haffner, Von Bismarck zu Hitler - Ein Rückblick; München 1989

[14] Hermann Hesse, Thomas Mann; Briefwechsel; Frankfurt am Main, 2003

[15] Wilhelm Hoegner, Die verratene Republik - Geschichte der deutschen Gegenrevolution; München, 1958

[16] Ludwig Hollweck, München in der zwanziger Jahren Zwischen Tradition und Fortschritt; München, 1982

[17] Michael H. Kater, The Nazy Party - A Social Profile of Members and Leaders 1919-1945; Oxford, 1983

[18] Ian Kershaw, Der NS-Staat; Hamburg, 2009

[19] Ian Kershaw, Popular Opinion and Political Dissent in the Third Reich: Bavaria 1933-45; Oxford, 1983

[20] Otto W. Johnston, Der deutsche Nationalmythos - Ursprung eines politischen Programms; Stuttgart, 1990

[21] Hans Kohn ; Wege und Irrwege - Vom Geist der deutschen Bürgertums; Düsseldorf, 1962

[22] Michael Loeckle, Die blockierte Republik - Deutschland zwischen Wahn und Wirklichkeit; Baden-Baden, 2004

[23] Maria Makela, The Munich Secession - Art and Artists in the Turn-of-the-Century Munich; Princeton, New Jersey, 1990

[24] Klaus Mann, MEPHISTO - Roman einer Karriere; Reinbek bei Hamburg, 2008
[25] Th. Mann, H. Mann, Leo Weismantel, Willi Geiger, Walter Courvoisier, Paul Renner, Kampf um München als Kulturzentrum; München, 1926

[26] Thomas Mann, München leuchtete; Ulm, 2008

[27] George L. Mosse, La nazionalizzazione delle masse; Bologna, 1975

[28] Anthony Nicholls and Erich Matthias (Ed by), German Democracy and the Triumph of Hitler - Essay on Recent German History; Edinburgh, 1971

[29] Dietrich Orlow, The History of the Nazi Party: 1919-1933; Pittsburgh, 1969

[30] Ernest R. Pope, Munich Playgorund; New York, 1941

[31] Kurt Preis, München unterm Hakenkreuz - Die Hauptstadt der Bewegung: Zwischen Pracht und Trümmern; München, 1980

[32] Eva G. Reichmann, Die Flucht in den Hass - Die Ursachen der deutschen Judenkatastrophe; Frankfurt am Main, 1956

[33] Joseph Roth; Das Spinnenetz; München 2007

[34] Pietro Scoppola, Lezioni sul Novecento; Bari, 2010

[35] Wolfram Selig (Hrsg), Aspekte der nationalsozialistischen Machtergreifung in München; München, 1983

[36] Kurt Sontheimer, Antidemokratisches Denken in der Weimarer Republik - Die politischen Ideen des deutschen Nationalismus zwischen 1918 und 1933; München, 1978

[37] Fritz Stern, Kulturpessimismus als politische Gefahr - Eine Analyse nationaler Ideologie in Deutschland; München, 1986

[38] Ernst Toller, Eine Jugend in Deutschland; Reinbek bei Hamburg, 2009

[39] Falk Wiesemann, Die Vorgeschichte der nationalsozialistischen Machtübernahme in Bayern 1932/33; Berlin, 1975

[40] Hermann Wilhelm, Dichter, Denker, Fememörder Rechtradikalismus und Antisemitismus in München von der Jahrhundertwende bis 1921; Berlin, 1989

[41] Wolfgang Wippermann, Der konsequente Wahn - Ideologie und Politik Adolf Hitlers; München, 1989 